\title{
Structural and Electrochemical Properties of Lithium Nickel Oxide Thin Films
}

\author{
Gyu-bong Cho, ${ }^{1}$ Tae-hoon Kwon, ${ }^{1}$ Tae-hyun Nam, ${ }^{1}$ Sun-chul Huh, ${ }^{2}$ Byeong-keun Choi, ${ }^{2}$ \\ Hyo-min Jeong, ${ }^{2}$ and Jung-pil Noh ${ }^{2}$ \\ ${ }^{1}$ School of Materials Science and Engineering and RIGECT, Gyeongsang National University, No. 501, Jinju-daero, Jinju, \\ Gyeongnam 660-701, Republic of Korea \\ ${ }^{2}$ Department of Energy and Mechanical Engineering and Institute of Marine Industry, Gyeongsang National University, \\ No. 38, Cheondaegukchi-gil, Tongyeong, Gyenognam 650-160, Republic of Korea \\ Correspondence should be addressed to Jung-pil Noh; nohjp@gnu.ac.kr
}

Received 19 June 2014; Revised 28 July 2014; Accepted 28 July 2014; Published 27 August 2014

Academic Editor: Yu Xin Zhang

Copyright (C) 2014 Gyu-bong Cho et al. This is an open access article distributed under the Creative Commons Attribution License, which permits unrestricted use, distribution, and reproduction in any medium, provided the original work is properly cited.

\begin{abstract}
$\mathrm{LiNiO}_{2}$ thin films were fabricated by RF magnetron sputtering. The microstructure of the films was determined by $\mathrm{X}$-ray diffraction and field-emission scanning electron microscopy. The electrochemical properties were investigated with a battery cycler using coin-type half-cells. The $\mathrm{LiNiO}_{2}$ thin films annealed below $500^{\circ} \mathrm{C}$ had the surface carbonate. The results suggest that surface carbonate interrupted the $\mathrm{Li}$ intercalation and deintercalation during charge/discharge. Although the annealing process enhanced the crystallization of $\mathrm{LiNiO}_{2}$, the capacity did not increase. When the annealing temperature was increased to $600^{\circ} \mathrm{C}$, the $\mathrm{FeCrNiO}{ }_{4}$ oxide phase was generated and the discharge capacity decreased due to an oxygen deficiency in the $\mathrm{LiNiO}_{2}$ thin film. The $\mathrm{ZrO}_{2}-$ coated $\mathrm{LiNiO}_{2}$ thin film provided an improved discharge capacity compared to bare $\mathrm{LiNiO}_{2}$ thin film suggesting that the improved electrochemical characteristic may be attributed to the inhibition of surface carbonate by $\mathrm{ZrO}_{2}$ coating layer.
\end{abstract}

\section{Introduction}

In an attempt to miniaturize high performance portable electronic equipment, batteries with high power and energy density are required. Thin film batteries have been developed in an attempt to satisfy this requirement [1-3]; however, improving the performance of the cathode films is critical for advancing the use of electrochemical thin film batteries. Among the possible materials that could be used for a cathode film, $\mathrm{LiCoO}_{2}$, owing to its high theoretical specific capacity and ease of preparation, is a promising candidate [4-6]. However, the high cost and toxicity of cobalt limit the use of $\mathrm{LiCoO}_{2}$ in thin film batteries. Therefore, it is necessary to develop less expensive cathode materials for thin film battery applications. $\mathrm{LiNiO}_{2}$ has emerged as a useful cathode material owing to its low cost and high energy density [7-10].

In the current study, $\mathrm{LiNiO}_{2}$ thin films were deposited by using RF magnetron sputtering. The microstructure of the films was measured by X-ray diffraction and field-emission scanning electron microscopy. Finally, the electrochemical properties were investigated with a battery cycler using cointype half-cells, in the potential range of $3.0 \mathrm{~V}-4.2 \mathrm{~V}$.

\section{Experimental}

Bare and $\mathrm{ZrO}_{2}$-coated $\mathrm{LiNiO}_{2}$ thin films have been deposited onto stainless steel (STS 304) foil substrates held at a distance of $6 \mathrm{~cm}$ away from the target. The STS304 substrate was ultrasonically cleaned with acetone, alcohol, and distilled water in that order. The $\mathrm{LiNiO}_{2}$ and $\mathrm{ZrO}_{2}$ targets were made by Pascal Co. (Japan). A base vacuum of $5 \times 10^{-6}$ Torr was obtained with a cryopump. Gas flow rate of $\mathrm{Ar} / \mathrm{O}_{2}$ was $4 / 1$ with a total gas flow amount of $150 \mathrm{sccm}$. Deposition pressure was maintained at $2 \times 10^{-3}$ Torr during deposition. The $\mathrm{LiNiO}_{2}$ target was presputtered for $30 \mathrm{~min}$ and the deposition time was 360 min at $100 \mathrm{~W}$ RF power. $\mathrm{ZrO}_{2}$ coating layer was deposited for $10 \mathrm{~min}$ at $100 \mathrm{~W}$ RF power. Figures 1(a) and 1(b) show the surface and cross-section images of bare $\mathrm{LiNiO}_{2}$ thin film deposited on Si wafer substrate. As seen in Figure 1(a), 


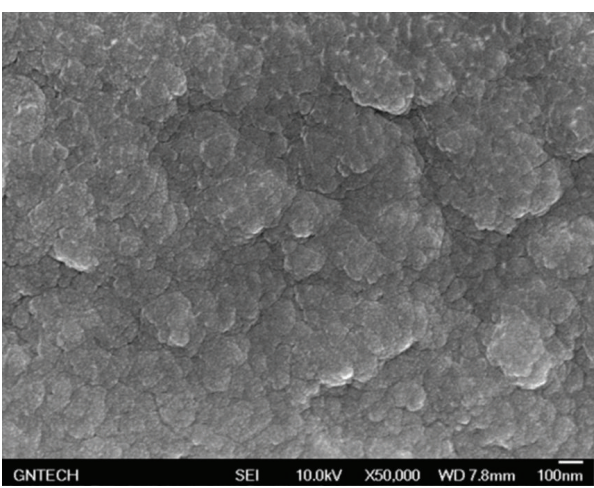

(a)

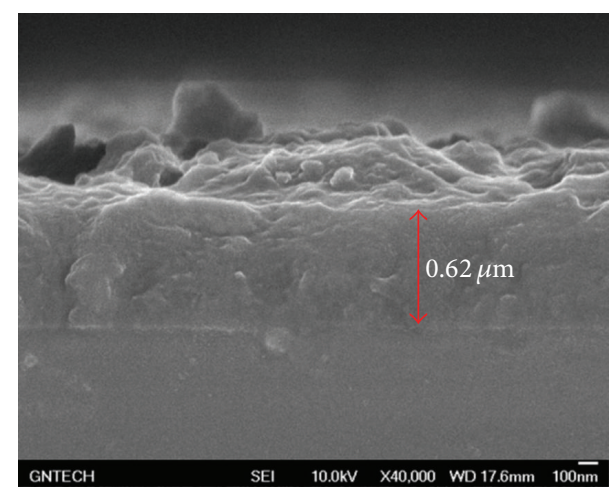

(b)

FIGURE 1: FE-SEM images of (a) surface and (b) cross-section images of $\mathrm{LiNiO}_{2}$ thin film deposited on Si wafer substrate.

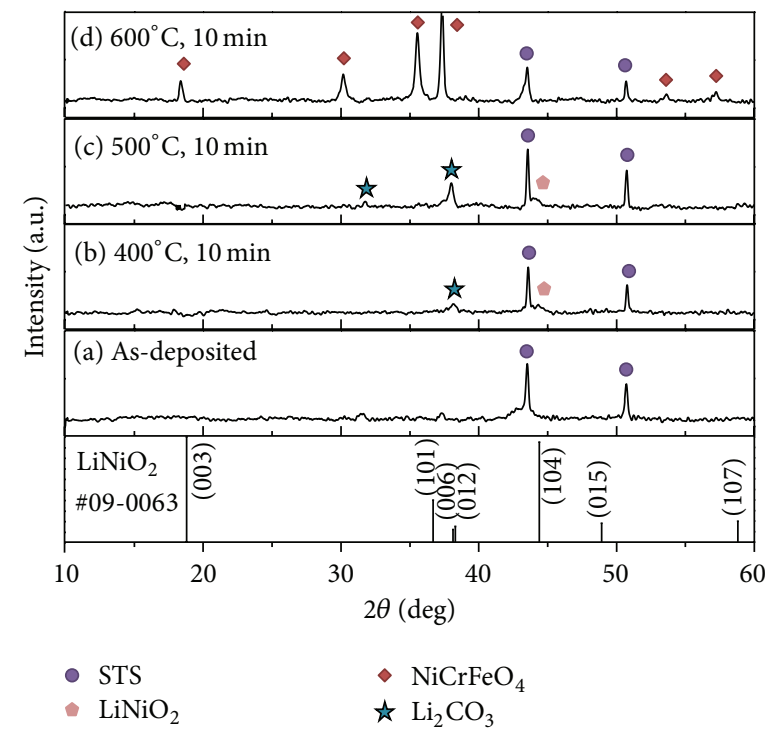

Figure 2: XRD patterns of (a) as-deposited, (b) $400^{\circ} \mathrm{C}$, (c) $500^{\circ} \mathrm{C}$, and (d) $600^{\circ} \mathrm{C}$ annealed $\mathrm{LiNiO}_{2}$ thin films. The annealing time was 10 minutes.

a uniform distribution of clusters of $\sim 50 \mathrm{~nm}$ was seen. The calculated deposition rates of $\mathrm{LiNiO}_{2}$ were approximately $1.7 \mathrm{~nm} / \mathrm{min}$. The deposited thin films were annealed from $400^{\circ} \mathrm{C}$ to $600^{\circ} \mathrm{C}$ in air to obtain the crystalline film.

The structure of the $\mathrm{LiNiO}_{2}$ thin films was investigated by X-ray diffractometry (XRD, Rigaku, Miniflex). The XRD measurements were performed using $\mathrm{Cu} K \alpha$ radiation $(\lambda=$ $1.5406 \AA$ ) and phase identification was made by comparing the diffraction patterns with the JCPDS references. The morphology of the deposited films was studied by fieldemission scanning electron microscopy (FE-SEM, Jeol, JSM6701F).

In order to examine the electrochemical properties of cathode thin films, coin-type cells were assembled with lithium foils as the counter and reference electrode and $1 \mathrm{M} \mathrm{LiPF}_{6}$ in ethylene carbonate (EC): diethyl carbonate (DEC) $(1: 1$, vol.\%) electrolytic solution. The charge-discharge test was carried out with a battery cycler (Won A Tech,
WDCS3000s) at a constant current density of $5 \mu \mathrm{A} / \mathrm{cm}^{2}$ in the potential range of $3.0-4.2 \mathrm{~V}$.

\section{Results and Discussion}

Figure 2 shows the XRD patterns of as-deposited and annealed $\mathrm{LiNiO}_{2}$ thin films at various temperatures at $10 \mathrm{~min}$. Crystallization peaks of $\mathrm{LiNiO}_{2}$ were not seen in the asdeposited films. However, the XRD pattern of the $400^{\circ} \mathrm{C}$ annealed film exhibited broad (104) $\mathrm{LiNiO}_{2}$ and lithium carbonate $\left(\mathrm{Li}_{2} \mathrm{CO}_{3}\right)$ reflection peaks. The degree of crystallization of $\mathrm{LiNiO}_{2}$ was enhanced at $500^{\circ} \mathrm{C}$ because the (104) reflection became stronger as the annealing temperature was increased. The intensity of the $\mathrm{Li}_{2} \mathrm{CO}_{3}$ peak also increased. However, after annealing at $600^{\circ} \mathrm{C}$, the reflection peaks of $\mathrm{LiNiO}_{2}$ and $\mathrm{Li}_{2} \mathrm{CO}_{3}$ disappeared and impurity peaks of $\mathrm{NiCrFeO}_{4}$, which was considered an oxide layer of the STS304 substrate, were observed (Figure 2(d)). 


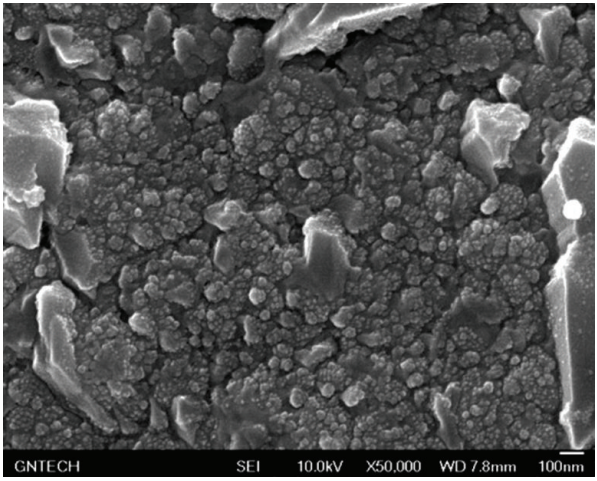

(a)

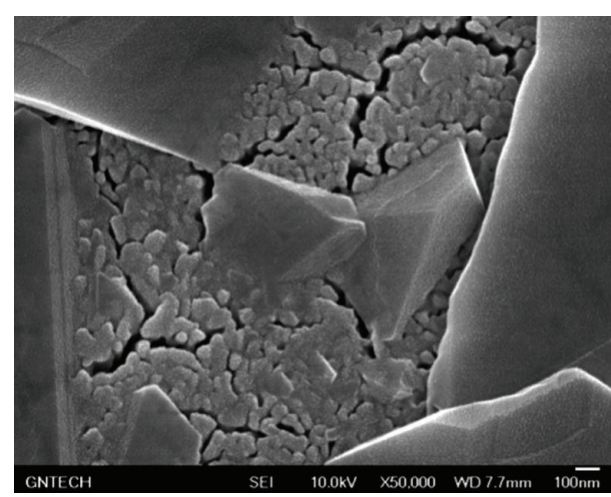

(b)

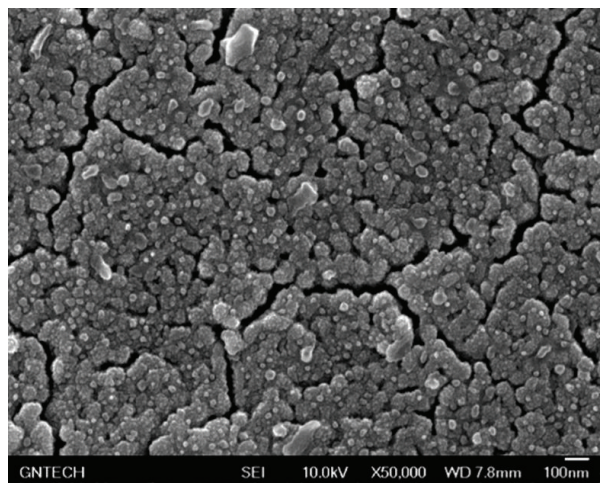

(c)

FIGURE 3: FE-SEM images of $\mathrm{LiNiO}_{2}$ thin film with various annealing temperatures at (a) $400^{\circ} \mathrm{C}$, (b) $500^{\circ} \mathrm{C}$, and (c) $600^{\circ} \mathrm{C}$, respectively. The annealing time was 10 minutes.

Surface images of the annealed $\mathrm{LiNiO}_{2}$ thin films are shown in Figure 3 . The $400^{\circ} \mathrm{C}$ annealed film had a rough surface with no cracks and some surface impurities (Figure 3(a)). When the annealing temperature was increased to $500^{\circ} \mathrm{C}$, the size of the surface impurities grew and became angular. After annealing at $600^{\circ} \mathrm{C}$, complete removal of the surface impurities was achieved and the surface had a smooth morphology compared with that of the $400^{\circ} \mathrm{C}$ annealed film. The XRD (Figure 2) and FE-SEM (Figure 3 ) results suggest that the angulated surface impurity, which disappeared at an annealing temperature of $600^{\circ} \mathrm{C}$, was lithium carbonate $\left(\mathrm{Li}_{2} \mathrm{CO}_{3}\right)$.

Figure 4 shows the initial discharge curves of the asdeposited and annealed $\mathrm{LiNiO}_{2}$ thin films. All of these films were tested at a current density of $5 \mu \mathrm{A} / \mathrm{cm}^{2}$ between $3.0 \mathrm{~V}$ and $4.2 \mathrm{~V}$ and a plateau was observed in the $400^{\circ} \mathrm{C}$ annealed films. When the annealing temperature was increased to $500^{\circ} \mathrm{C}$, the plateau was more clearly exhibited and indicated a phase transition of crystalline $\mathrm{LiNiO}_{2}[11,12]$; the discharge capacity, however, did not increase. These results suggest that the surface carbonate interrupts the lithium intercalation and deintercalation during charge/discharge, affecting the discharge capacity. The $600^{\circ} \mathrm{C}$ annealed films exhibited a lower initial discharge capacity compared with the other annealed films. This may be attributed to the formation of an intermediate oxide layer between the substrate and

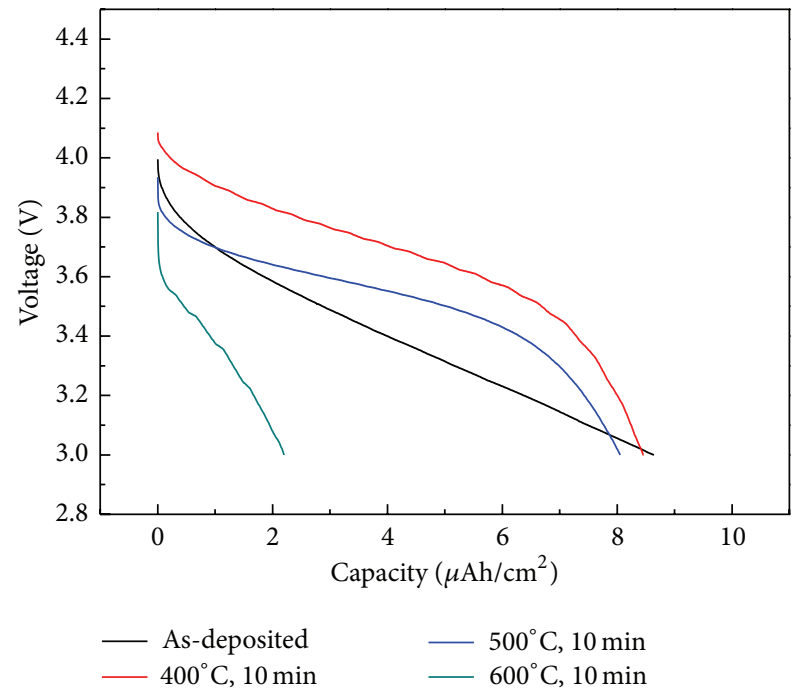

FIGURE 4: Initial discharge curves of $\mathrm{LiNiO}_{2}$ thin film with various annealing temperatures. The annealing time was 10 minutes.

active material film. The intermediate oxide layer that formed may lead to an oxygen deficiency in the annealed $\mathrm{LiNiO}_{2}$ thin films. In order for the $\mathrm{LiNiO}_{2}$ film to obtain good electrochemical characteristics, the deposited $\mathrm{LiNiO}_{2}$ thin 


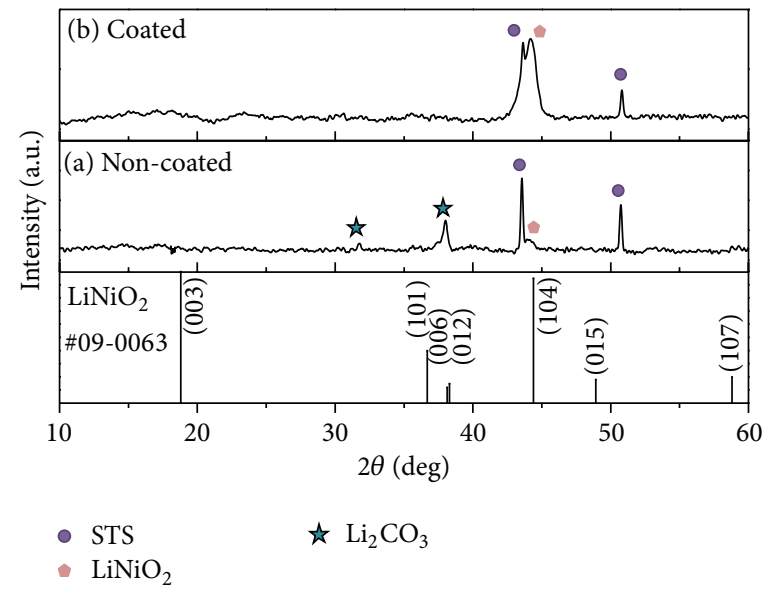

Figure 5: XRD patterns of (a) noncoated and (b) $\mathrm{ZrO}_{2}$-coated $\mathrm{LiNiO}_{2}$ thin films. The films were annealed in $10 \mathrm{~min}$ at $500^{\circ} \mathrm{C}$.

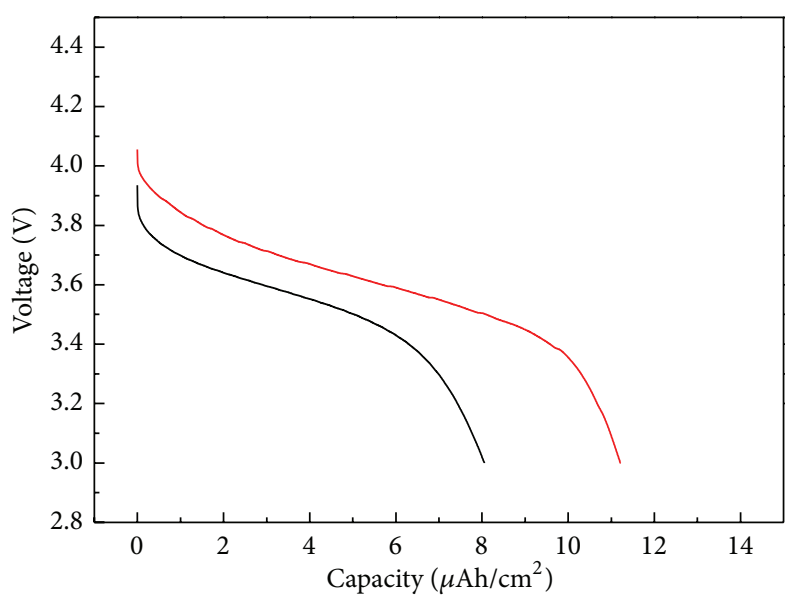

Noncoated
Coated

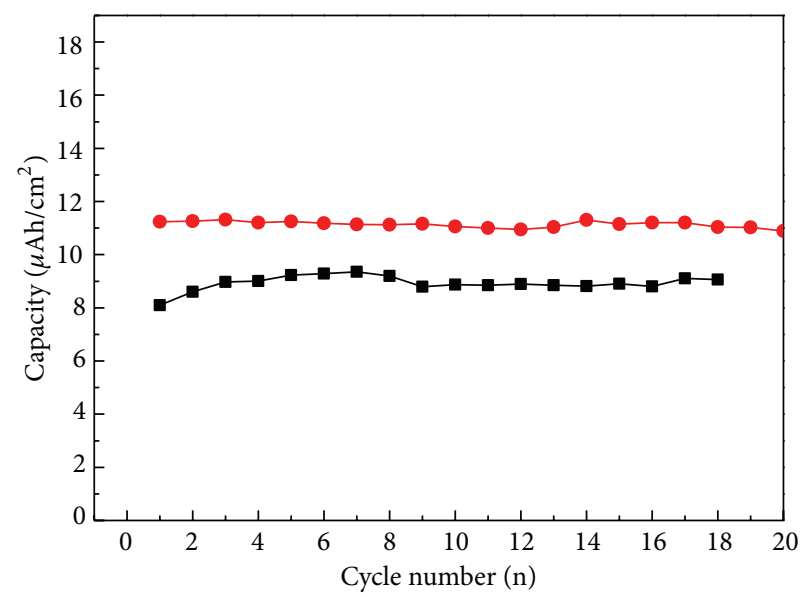

$\rightarrow$ Noncoated

(a)

(b)

FIGURE 6: (a) Initial discharge behavior and (b) cyclic performance of $\mathrm{LiNiO}_{2}$ thin films. The films were annealed in 10 min at $500^{\circ} \mathrm{C}$.

films should be annealed at a temperature that prevents the formation of an intermediate oxide layer. In addition, it is necessary to remove the surface carbonate. It has been previously reported that surface coatings enhance the electrochemical properties of cathode materials without sacrificing the specific capacity of the respective cathode [13].

Figure 5 shows the XRD patterns of bare and $\mathrm{ZrO}_{2}$-coated $\mathrm{LiNiO}_{2}$ thin films annealed at $500^{\circ} \mathrm{C}$ for $10 \mathrm{~min}$. As seen in Figure 5(a), the diffraction peak of the surface carbonate disappeared in the coated thin film, suggesting that the $\mathrm{ZrO}_{2}$ coating prevents the formation of surface carbonate during the annealing process.

Figure 6 shows the first discharge curves and cycle stability of bare and $\mathrm{ZrO}_{2}$-coated $\mathrm{LiNiO}_{2}$ thin films. As seen in Figures 6(a) and 6(b), a single plateau was observed in both of the films, corresponding to the phase transition of crystalline $\mathrm{LiNiO}_{2}$. Therefore, this would indicate that both films are crystallized. However, the first discharge capacity is slightly different such that the first discharge capacity of $\mathrm{ZrO}_{2}$-coated film is higher than that of the bare $\mathrm{LiNiO}_{2}$ thin film. The capacity retention rate is similar in both thin films as seen in Figure 6(b).

\section{Summary}

$\mathrm{LiNiO}_{2}$ thin films were fabricated by RF magnetron sputtering. Crystallization began at annealing temperatures above $400^{\circ} \mathrm{C}$; however, the films that were annealed below $500^{\circ} \mathrm{C}$ exhibited surface carbonate (in the form of $\mathrm{Li}_{2} \mathrm{CO}_{3}$ ) identified by XRD. Surface carbonate interrupts the Li intercalation and deintercalation during charge/discharge and therefore the capacity did not increase, although the degree of $\mathrm{LiNiO}_{2}$ crystallization was enhanced. When the annealing temperature was increased to $600^{\circ} \mathrm{C}$, the $\mathrm{FeCrNiO}_{4}$ oxide phase was generated and the discharge capacity decreased due to 
the oxygen deficiency in the $\mathrm{LiNiO}_{2}$ thin film. The $\mathrm{ZrO}_{2}-$ coated $\mathrm{LiNiO}_{2}$ thin film provided an improved discharge capacity compared to the bare $\mathrm{LiNiO}_{2}$ thin film at an annealing temperature of $500^{\circ} \mathrm{C}$. Therefore, the improvement in electrochemical characteristics can be attributed to the inhibition of surface carbonate by the $\mathrm{ZrO}_{2}$ coating layer.

\section{Conflict of Interests}

The authors declare that there is no conflict of interests regarding the publication of this paper.

\section{Acknowledgment}

This research was supported by the Science Research Program through the National Research Foundation of Korea (NRF) funded by the Ministry of Education, Science and Technology (2012-R1A1A2008821 and 2012R1A2A1A01006546).

\section{References}

[1] Y. Iriyama, C. Yada, T. Abe, Z. Ogumi, and K. Kikuchi, "A new kind of all-solid-state thin-film-type lithium-ion battery developed by applying a D.C. high voltage," Electrochemistry Communications, vol. 8, no. 8, pp. 1287-1291, 2006.

[2] S. J. Lee, H. K. Baik, and S. M. Lee, "An all-solid-state thin film battery using LISIPON electrolyte and $\mathrm{Si}-\mathrm{V}$ negative electrode films," Electrochemistry Communications, vol. 5, no. 1, pp. 32-35, 2003.

[3] Y. J. Kim, H. Kim, B. Kim et al., "Electrochemical stability of thin-film $\mathrm{LiCoO}_{2}$ cathodes by aluminum-oxide coating," Chemistry of Materials, vol. 15, no. 7, pp. 1505-1511, 2003.

[4] G. G. Amatucci, J. M. Tarascon, and L. C. Klein, " $\mathrm{CoO}_{2}$, the end member of the $\mathrm{Li}_{x} \mathrm{CoO}_{2}$ solid solution," Journal of The Electrochemical Society, vol. 143, no. 3, pp. 1114-1123, 1996.

[5] K. Edstrom, T. Gustafsson, and J. O. Thomas, "The cathodeelectrolyte interface in the Li-ion battery," Electrochimica Acta, vol. 50, no. 2-3, pp. 397-403, 2004.

[6] J. H. Kim, M. Y. Eom, S. W. Noh, and D. W. Shin, "Performance optimization of all-solid-state lithium ion batteries using a $\mathrm{Li}_{2} \mathrm{~S}$ $\mathrm{P}_{2} \mathrm{~S}_{5}$ solid electrolyte and $\mathrm{LiCoO}_{2}$ cathode," Electronic Materials Letters, vol. 8, pp. 209-213, 2012.

[7] H. Arai, S. Okada, H. Ohtsuka, M. Ichimura, and J. Yamaki, "Characterization and cathode performance of $\mathrm{Li}_{1-\mathbf{x}} \mathrm{Ni}_{1+\mathbf{x}} \mathrm{O}_{2}$ prepared with the excess lithium method," Solid State Ionics, vol. 80, pp. 261-269, 1995.

[8] S. H. Ju, J. H. Kim, and Y. C. Kang, "Electrochemical properties of $\mathrm{LiNi}_{0.8} \mathrm{Co}_{0.2-x} \mathrm{Al}_{x} \mathrm{O}_{2}(0 \leq \mathrm{x} \leq 0.1)$ cathode particles prepared by spray pyrolysis from the spray solutions with and without organic additives," Matals and Materials International, vol. 16, no. 2, pp. 299-303, 2010.

[9] S. N. Kwon, J. Song, and D. R. Mumm, "Effects of cathode fabrication conditions and cycling on the electrochemical performance of $\mathrm{LiNiO}_{2}$ synthesized by combustion and calcination," Ceramics International, vol. 37, no. 5, pp. 1543-1548, 2011.

[10] M. Y. Song, C. K. Park, H. R. Park, and D. R. Mumm, "Variations in the electrochemical properties of metallic elementssubstituted $\mathrm{LiNiO}_{2}$ cathodes with preparation and cathode fabrication conditions," Electronic Materials Letters, vol. 8, no. 1, pp. 37-42, 2012.
[11] J. Cho, T. Kim, Y. J. Kim, and B. Park, "High-performance $\mathrm{ZrO}_{2}$ coated $\mathrm{LiNiO}_{2}$ cathode material," Electrochemical and SolidState Letters, vol. 4, no. 10, pp. A159-A161, 2001.

[12] E. Endo, T. Yasuda, K. Yamaura, A. Kita, and K. Sekai, " $\mathrm{LiNiO}_{2}$ electrode modified by plasma chemical vapor deposition for higher voltage performance," Journal of Power Sources, vol. 93, no. 1-2, pp. 87-92, 2001.

[13] J. Kim, C. S. Johnson, J. T. Vaughey et al., "The electrochemical stability of spinel electrodes coated with $\mathrm{ZrO}_{2}, \mathrm{Al}_{2} \mathrm{O}_{3}$, and $\mathrm{SiO}_{2}$ from colloidal suspensions," Journal of the Electrochemical Society, vol. 151, no. 10, pp. A1755-A1761, 2004. 

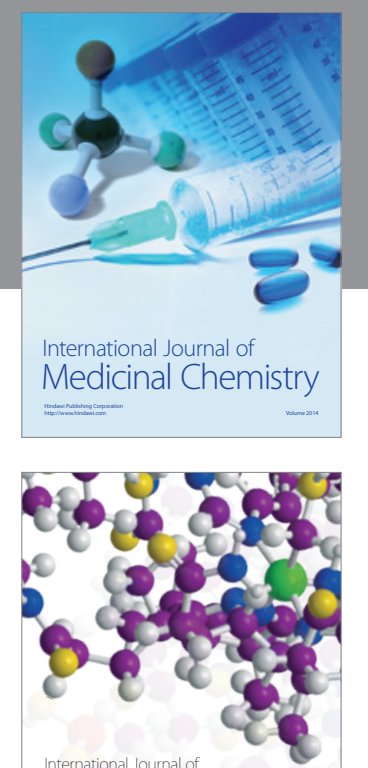

\section{Carbohydrate} Chemistry

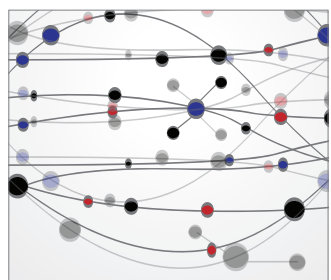

The Scientific World Journal
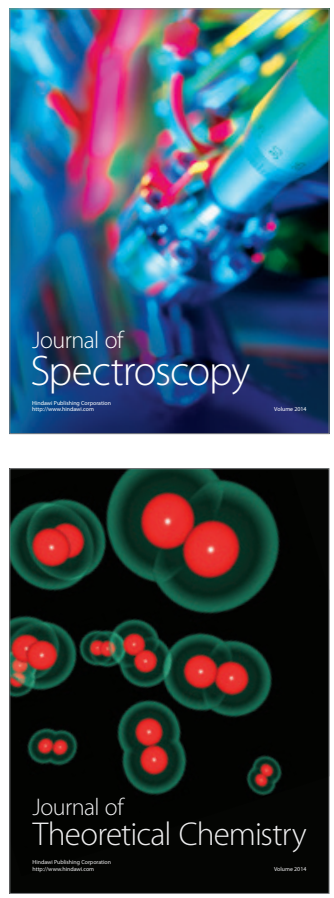
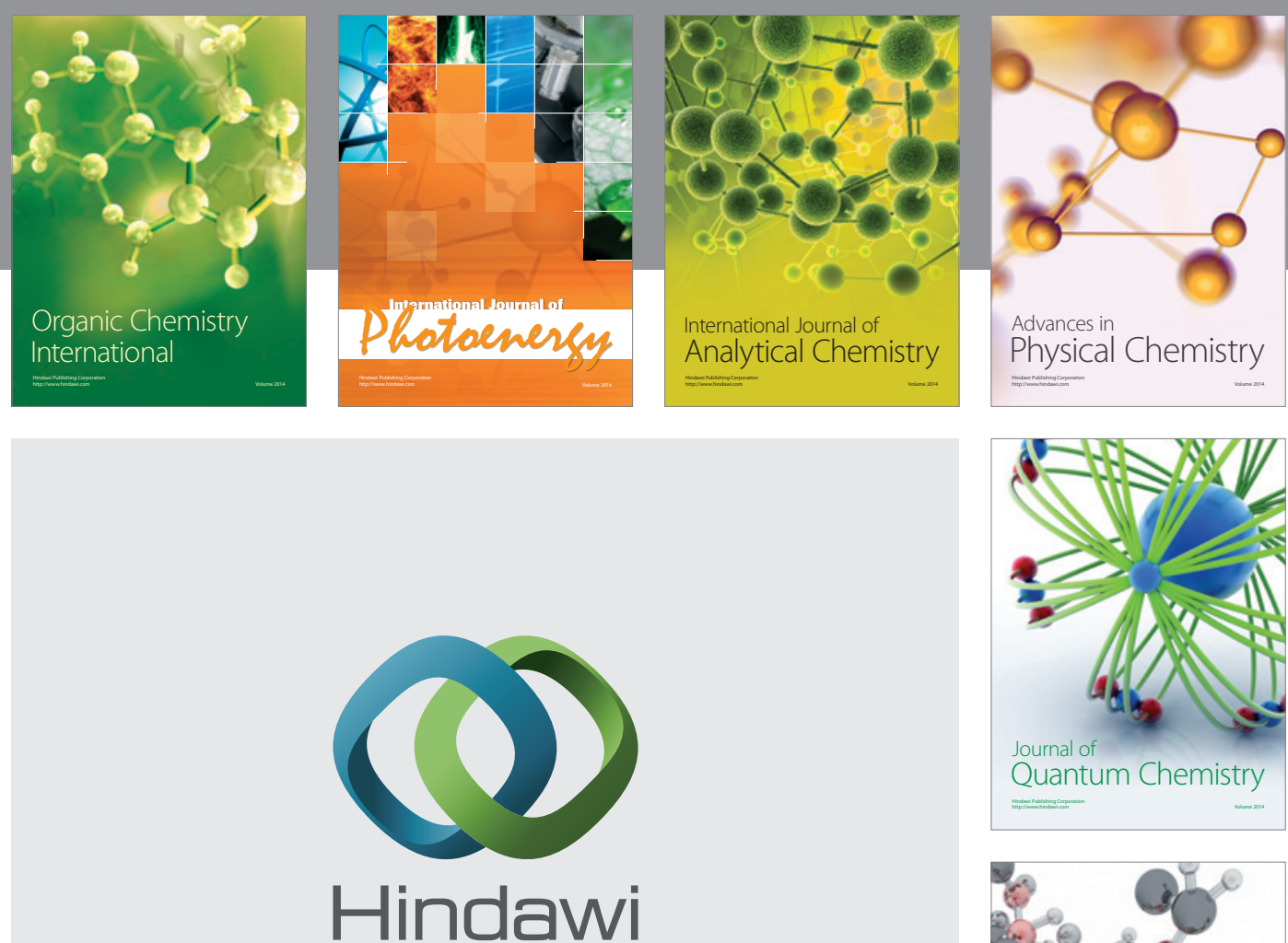

Submit your manuscripts at

http://www.hindawi.com

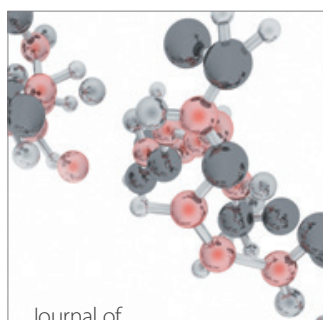

Analytical Methods

in Chemistry

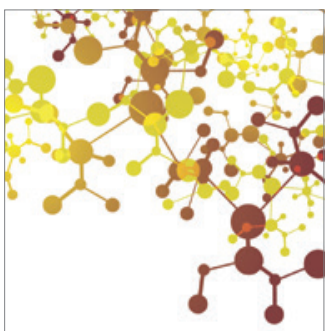

Journal of

Applied Chemistry

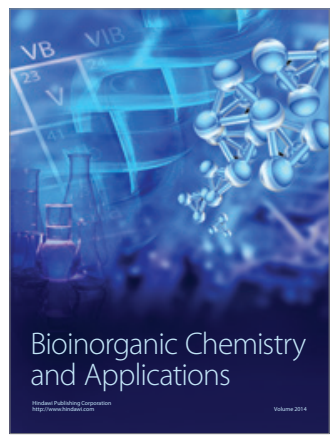

Inorganic Chemistry
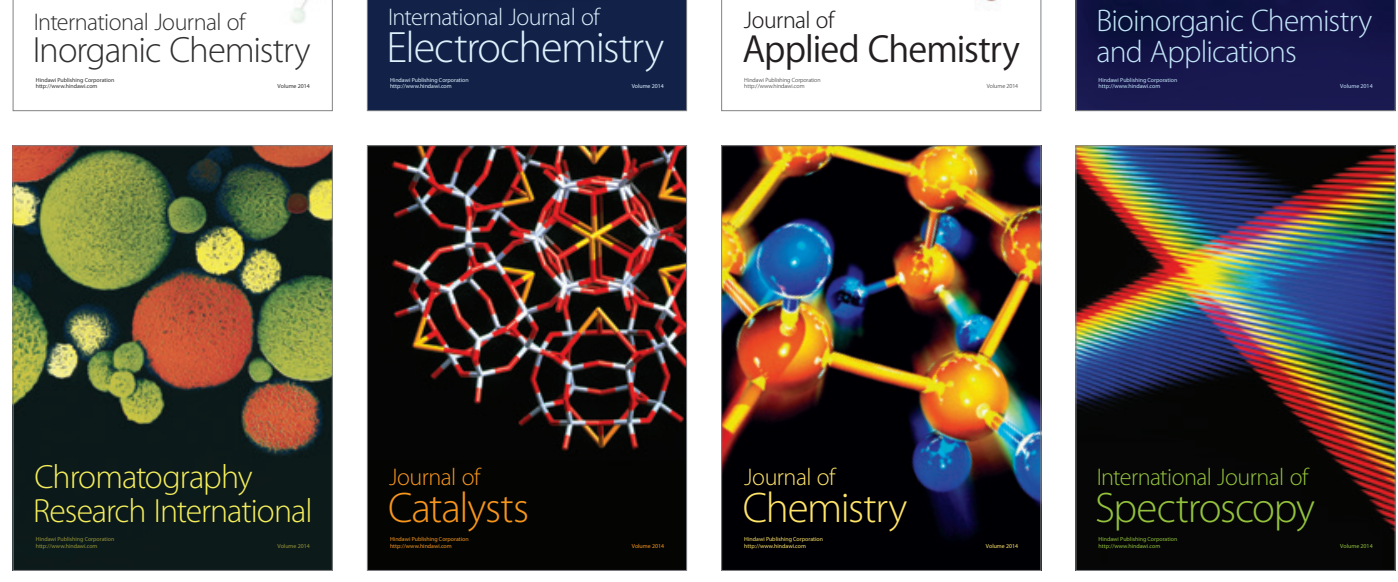